\title{
Vrije advocaatkeuze en rechtsbijstandverzekeringen
}

\author{
Prof. mr. H.B. Krans en F.Q. van de Pol*
}

\begin{abstract}
1 Inleiding
Heeft een verzekerde met een rechtsbijstandverzekering recht op vrije keuze van een advocaat? Het recht op vrije keuze van een advocaat bij rechtsbijstandverzekeringen wordt wel gezien als een fundamenteel recht van de verzekerde. ${ }^{1}$ Uit de Richtlijn rechtsbijstandverzekeringen volgt ook dat een verzekerde in beginsel recht op vrije keuze van een advocaat heeft. ${ }^{2}$

De reikwijdte van het recht op vrije advocaatkeuze bij rechtsbijstandverzekeringen is sinds enige tijd met zekere regelmaat voorwerp van debatten in rechte. Van verzekeraarszijde wordt een beperkte interpretatie van het recht bepleit. ${ }^{3}$ Verzekerden staan daarentegen een ruimere opvatting voor om een eigen keuze voor een advocaat te kunnen maken. ${ }^{4}$

Procedures over de reikwijdte van het recht op vrije keuze bij rechtsbijstandverzekeringen zijn geenszins beperkt tot het nationale Nederlandse speelveld. Het Europese Hof van Justitie heeft in de afgelopen jaren diverse arresten gewezen over de reikwijdte van de vrije advocaatkeuze. Die rechtspraak is ook van belang voor de Nederlandse rechtspraktijk.

De Richtlijn rechtsbijstandverzekeringen, thans opgenomen in de Richtlijn Solvabiliteit II, ${ }^{5}$ is in Nederland geïmple-
\end{abstract}

* Prof. mr. H.B. Krans is hoogleraar Burgerlijk recht en Burgerlijk procesrecht aan de Universiteit Leiden. F.Q. van de Pol was student-assistent aan de Universiteit Leiden en studeert thans aan de London School of Economics and Political Science.

De auteurs danken Gijs Molkenboer en Willem van Boom voor hun nuttige opmerkingen en suggesties bij een eerdere versie.

1. Zie bijv. T.M.M.P. Westbroek, 'De vrije advocaatkeuze in de rechtsbijstandspolis: rechtsonzekerheid troef?', Het Verzekerings-Archief 1997, afl. 4, p. 148. Westbroek spreekt van een 'fundamentele waarde in onze rechtsstaat'. Ook is erop gewezen dat rechtsbijstandverzekeringen zorgen voor een betere toegang tot het recht.

2. Zie art. 4 Richtlijn $87 / 344 /$ EEG van de Raad van 22 juni 1987 tot coördinatie van de wettelijke en bestuursrechtelijke bepalingen betreffende de rechtsbijstandverzekering, PbEG 1987, L 185 (hierna: Richtlijn rechtsbijstandverzekeringen).

3. Zie W.H. van Boom, 'Enige recente ontwikkelingen in de particuliere rechtsbijstandverzekering, $T v C$ 2011, afl. 1, p. 9 (die ook wijst op het verdienmodel van verzekeraars) en eerder het rapport van de Interdepartementale Werkgroep Domeinmonopolie Advocatuur, Project marktwerking, deregulering en wetgevingskwaliteit, 1995, p. 40-41.

4. Naast de standpunten van partijen is er overigens een meer algemeen perspectief: het maatschappelijk belang om de kosten van rechtsbijstand betaalbaar te houden.

5. Richtlijn 2009/138/EG van het Europees Parlement en de Raad van 25 november 2009 betreffende de toegang tot en uitoefening van het verzekerings- en het herverzekeringsbedrijf (Solvabiliteit II). menteerd in de Wet op het financieel toezicht (Wft). ${ }^{6} \mathrm{De} \mathrm{Wft}$ is weliswaar relevant voor de interpretatie van het recht op vrije advocaatkeuze, maar de onderliggende Europese richtlijn en de uitleg die het Europese Hof daaraan geeft, dienen daarbij vanzelfsprekend in acht genomen te worden.

In deze bijdrage bezien wij de ontwikkelingen in de Europese rechtspraak over dit recht op vrije advocaatkeuze in de afgelopen jaren en de betekenis daarvan voor het Nederlandse recht. Eerst gaan wij in op het recht op vrije advocaatkeuze bij rechtsbijstandverzekeringen meer in het algemeen (par. 2). Daarna bespreken we de Europese stroomversnelling waarin de ontwikkelingen rondom dit recht de afgelopen jaren zijn beland (par. 3). Paragraaf 4 betreft enkele gevolgen van deze ontwikkelingen voor ons land, waarna paragraaf 5 de gevolgen voor verzekerden beschouwt. Paragraaf 6 sluit af.

\section{Richtlijn rechtsbijstandverzekeringen}

\subsection{Ratio vrije keuze}

De Richtlijn rechtsbijstandverzekeringen was de eerste Europese richtlijn waarin deze verzekeringen inhoudelijk werden geregeld. Ter bevordering van de interne markt werd het wenselijk geacht rechtsbijstandverzekeringen tot op zekere hoogte te harmoniseren. ${ }^{7}$ In de considerans van de Richtlijn rechtsbijstandverzekeringen wordt het voorkomen van belangenconflicten tussen verzekerden en verzekeraars benoemd. ${ }^{8}$ Verzekeraars kunnen prikkels ondervinden om niet overal optimale rechtsbijstand te verlenen. Holthinrichs heeft bijvoorbeeld gewezen op de situatie dat een verzekeraar twee strijdende partijen heeft verzekerd, de ene partij voor rechtsbijstand en de andere partij voor een andere verzekering, bijvoorbeeld een

6. Op grond van art. 4:67 lid $1 \mathrm{Wft}$ (welke bepaling strekt ter implementatie van art. 4 Richtlijn rechtsbijstandverzekeringen) draagt een rechtsbijstandverzekeraar er zorg voor dat in de overeenkomst inzake rechtsbijstanddekking uitdrukkelijk wordt bepaald dat het de verzekerde vrijstaat een advocaat te kiezen om zijn belangen in een gerechtelijke of administratieve procedure te verdedigen, te vertegenwoordigen of te behartigen, of indien zich een belangenconflict voordoet.

7. De Richtlijn behelst overigens wel minimumharmonisatie (waarover D.B. Holthinrichs, 'De vrije advocaatkeuze in rechtsbijstandverzekeringen en Richtlijn 87/344/EEG: keuze voor de verzekerde of verplichting voor de verzekeraar?', NTHR 2013, afl. 3, p. 164).

8. Met het oog op de bescherming van verzekerden moet elk mogelijk belangenconflict tussen een voor rechtsbijstand verzekerde en zijn verzekeraar voor bepaalde branches zo veel mogelijk worden voorkomen en als het zich voordoet, moet de oplossing ervan mogelijk worden gemaakt, aldus (samengevat) de vierde alinea van de considerans. 
aansprakelijkheidsverzekering. De verzekeraar kan er vanuit bedrijfseconomisch perspectief dan belang bij hebben om de rechtsbijstand niet optimaal te verlenen. ${ }^{9}$ Ook is mogelijk dat twee partijen beide bij dezelfde verzekeraar zijn verzekerd voor rechtsbijstand. Op de voet van art. 4 lid 1 sub b van de richtlijn moeten verzekerden alsdan vrij zijn een advocaat te kiezen. Het gevaar van belangenconflicten behoeft zich overigens niet te manifesteren. Een verzekeraar kan er belang bij hebben de relatie met de verzekerde goed te houden, bijvoorbeeld omdat de verzekering voor onbepaalde tijd is afgesloten of omdat de verzekerde meer dan één verzekering heeft afgesloten. ${ }^{10}$ Toch is het begrijpelijk dat getracht is bedoelde belangenverstrengelingen te voorkomen, gezien de mogelijke gevolgen daarvan voor de verzekerde. Er kan daarnaast nog een reden worden genoemd voor het recht op vrije advocaatkeuze: dat recht kan ertoe strekken te bereiken dat de ingeschakelde advocaat zonder vooringenomenheid te werk zal kunnen gaan. ${ }^{11}$

Gesteld kan worden dat aan het recht op vrije advocaatkeuze in Europese rechtspraak van recente jaren, waarover meer in paragraaf 3 , meer gewicht is toegekend.

\subsection{Diverse waarborgen}

Via verschillende routes beoogt de richtlijn de vrije advocaatkeuze te bereiken. ${ }^{12}$ In art. 3 worden waarborgen voorgeschreven die bestaan uit organisatorische maatregelen bij de verzekeraar ter voorkoming van belangenverstrengeling. Dit artikel is geimplementeerd in art. 4:65 Wft. De verzekeraar moet 'Chinese Walls' aanleggen tussen zijn rechtsbijstandafdeling en andere afdelingen, de schaderegeling uitbesteden aan een strikt afgescheiden juridisch zelfstandige onderneming of het recht op vrije advocaatkeuze opnemen in de verzekeringsovereenkomst. ${ }^{13}$ Deze maatregelen worden als gelijkwaardig gezien. De richtlijn laat de lidstaten vrij om een van de maatregelen dwingend voor te schrijven of de keuze te laten aan de verzekeraars zelf. ${ }^{14}$ In Nederland is de keuze overgelaten aan de verzekeraars, met uitzondering van verzekeraars die naast de branche rechtsbijstand nog een andere branche uitoefenen (zogeheten 'multibrancheverzekeraars'). ${ }^{15}$ De eerste twee maatregelen passen bij een verzekering in natura, waarbij de verzekeraar zelf de rechtsbijstandsdiensten verleent. De laatste

9. Holthinrichs 2013, p. 160 l.k.

10. Doordat verzekeringen doorgaans voor onbepaalde tijd worden afgesloten en er meerdere verzekeringen worden afgenomen, bestaat er vaak een langdurige relatie tussen verzekeraar en verzekerde. Hierdoor heeft de verzekeraar juist ook weer een prikkel kwaliteit te leveren en de verzekerde tevreden te houden, hetgeen het gevaar van een belangenconflict enigszins dempt. Zie Interdepartementale Werkgroep Domeinmonopolie Advocatuur 1995, p. 41.

11. Vgl. $\operatorname{COM(79)396~def.,~p.~6,~waarin~de~Europese~Commissie~stelt~dat~de~}$ advocaat in een moeilijke positie zou belanden wanneer hij de vaste advocaat is van de verzekeringsmaatschappij, vooral wanneer deze meerdere branches uitoefent. Zie Holthinrichs 2013, p. 161.

12. Respectievelijk art. 3 lid 2 en 4 lid 1 Richtlijn rechtsbijstandverzekeringen. Deze bepalingen zijn per 25 november 2009 herschikt tot art. 200-201 Richtlijn Solvabiliteit II (2009/138/EG).

13. Respectievelijk art. 3 lid 2 sub a, b en c Richtlijn rechtsbijstandverzekeringen.

14. Zie art. 3 lid 2 aanhef Richtlijn rechtsbijstandverzekeringen.

15. Zie art. 4:65 lid 1 en 2 Wft en Kamerstukken II 1988/89, 21076, 3, p. 3. maatregel heeft meer weg van een kostenverzekering, waarbij de verzekerde zijn advocatenkosten kan declareren. Deze laatste oplossing zal waarschijnlijk het duurste uitpakken voor de verzekeraar. $^{16}$

Er zijn ook waarborgen neergelegd in het al genoemde art. 4 van de richtlijn, geïmplementeerd in art. 4:67 Wft. Sub a van die bepaling schrijft voor dat in elke rechtsbijstandsovereenkomst uitdrukkelijk moet worden bepaald dat indien een advocaat of andere rechtens bevoegde deskundige wordt gevraagd de belangen van de verzekerde te verdedigen in een gerechtelijke of administratieve procedure, de verzekerde vrij is om een advocaat of deskundige te kiezen. Dit is een dwingend voorschrift. ${ }^{17}$ Verzekerden moeten dus op het recht op vrije advocaatkeuze worden geattendeerd. Ook voor gevallen waarin zich daadwerkelijk een belangenconflict voordoet en de noodzaak is ontstaan dat het dossier 'buiten de verzekeraar' verder wordt behandeld, is de verzekerde vrij om een advocaat of andere gekwalificeerde deskundige te kiezen. ${ }^{18}$ Deze waarborgen zijn complementair aan de algemene vrije advocaatkeuze ex art. 3 lid 2 sub c, maar zijn voor de rechtspraktijk het meest interessant. Waar onder art. 3 lid 2 immers de keuze aan de verzekeraar wordt gelaten, zal deze, gezien de bijkomende kosten, niet snel kiezen voor de algemene vrije advocaatkeuze. ${ }^{19} \mathrm{~W}$ ij focussen dan ook op het recht op vrije advocaatkeuze als externe waarborg op grond van art. 4. Het Hof van Justitie legt daar in zijn rechtspraak de nadruk op.

Naar aanleiding van de implementatie van art. 4 van de richtlijn in art. 4:67 Wft heeft de wetgever aanvankelijk aangegeven dat deze vrije advocaatkeuze niet absoluut is. Bedacht zij dat Nederland een tamelijk unieke positie inneemt binnen de EU qua rechtshulpverlening. ${ }^{20}$ De naturaverzekering floreert - of misschien: floreerde - vanwege de relatief gezien ruime mogelijkheden zonder advocaat te procederen. Vandaar dat destijds volgens de wetgever de vrije advocaatkeuze pas aan de orde kwam indien de rechtsbijstandverzekeraar bij een naturaverzekering besloot dat een advocaat of andere bevoegde deskundige ingeschakeld dient te worden. ${ }^{21}$ Een verzekerde kon een verzekeraar dus niet dwingen een advocaat in de arm te

16. In gelijke zin Holthinrichs 2013, p. 161.

17. Dit dwingende karakter blijkt uit de bewoordingen van de bepaling, maar is ook bevestigd door het Hof van Justitie (HvJ EG 10 september 2009, C-199/08, ECLI:EU:C:2009:538, NJ 2009/593 (Eschig/Uniqa), sub 47-48).

18. Art. 4 lid 1 sub b Richtlijn rechtsbijstandverzekeringen. Zie over dit belangenconflict T.W.J. Goettsch, 'Vrije advocaatkeuze: rationele regeling of - opnieuw - regeling van de rechtshulpmarkt?', NJB 1997, p. 536, Holthinrichs 2013 en Kamerstukken II 2013/14, 33918, 10, p. 12.

19. Vgl. Goettsch 1997, p. 535.

20. Holthinrichs 2013, p. 157.

21. Indien onder art. 4:65 lid 1 sub c of lid 2 sub b Wft is gekozen om als 'interne' waarborg (ex art. 3 Richtlijn rechtsbijstandverzekeringen) de vrije advocaatkeuze op te nemen in de overeenkomst is de vrije advocaatkeuze uit art. 4:67 lid $1 \mathrm{Wft}$ (art. 4 Richtlijn rechtsbijstandverzekeringen) niet meer van toepassing (art. 4:67 lid $2 \mathrm{Wft}$ ). Zie over het standpunt van de wetgever destijds Kamerstukken II 1988/89, 21076, 3, p. 4, 5 en 6 en Kamerstukken II 2005/06, 29708, 19, p. 541. 
nemen. ${ }^{22}$ Dit standpunt van de Nederlandse wetgever is, zoals hierna zal blijken, in het licht van ontwikkelingen in de rechtspraak niet meer houdbaar. De wetgever is hiervan dan ook grotendeels teruggekomen. ${ }^{23}$

\section{Een stroomversnelling}

De Richtlijn rechtsbijstandverzekeringen, vastgesteld in 1987, diende per 1990 te zijn geïmplementeerd. De rechtspraak over de richtlijn en de uitleg daarvan kwamen vooral op gang in het eerste decennium van de 21 ste eeuw. Diverse vragen in verband met het recht op vrije advocaatkeuze werden, als gezegd, voorgelegd aan het Europese Hof van Justitie.

\subsection{Vrije keuze bij massaschade?}

In 2009 oordeelt het Europese Hof over het recht op vrije advocaatkeuze in een geval dat als massaschadezaak zou kunnen worden betiteld. ${ }^{24}$ Door insolventie van twee Oostenrijkse beleggingsmaatschappijen hadden enkele duizenden beleggers schade geleden. Een van de beleggers, de heer Eschig, gaf daarop een advocatenkantoor opdracht zijn schade te verhalen op de twee ondernemingen en verzocht zijn rechtsbijstandverzekeraar Uniqa toe te zeggen dat hij de advocatenkosten kon declareren. De verzekeraar weigerde en stelde dat hij van zijn schadelijdende verzekerden mocht verlangen dat zij tezamen deelnemen aan een proefproces respectievelijk collectieve actie, en dat de verzekeraar in zo'n geval de rechtshulpverlener kon aanwijzen. De verzekeraar wees in dit verband naar de toepasselijk verklaarde algemene voorwaarden. ${ }^{25}$ Eschig vorderde daarop bij het Landesgericht Salzburg vast te stellen dat Uniqa verplicht is zijn advocatenkosten te vergoeden en dat de desbetreffende bepalingen uit de algemene voorwaarden nietig zijn. Nadat het daartegen ingestelde beroep door het Oberlandesgericht was verworpen en Eschig zich tot het Oberste Gerichtshof heeft gewend, stelt dit gerecht vragen aan het Europese Hof. De Oostenrijkse rechter wil vernemen of art. 4 van de richtlijn zo moet worden uitgelegd dat de rechtsbijstandverzekeraar zich het recht mag voorbehouden om zelf de rechtshulpverlener voor alle betrokken verzekerden te kiezen als een groot aantal verzekeringsnemers schade lijdt door hetzelfde feit.

Het Hof van Justitie overweegt dat art. 4 van de richtlijn zo moet worden uitgelegd dat de rechtsbijstandverzekeraar zich niet het recht kan voorbehouden zelf de rechtshulpverlener voor alle betrokken verzekerden te kiezen wanneer een

22. De status van de Europese travaux préparatoires is lang niet hetzelfde als de status van de Nederlandse parlementaire bescheiden bij wetgeving. Maar uit de relevante travaux préparatoires kan worden afgeleid dat de Commissie die ruimte heeft geboden omdat zij zich niet wilde mengen in de binnen de lidstaten geldende gebruiken (SURE 35, werkdocument nr. 10836/82 van de Groep Economische Vraagstukken van 10 november 1982 , p. 5$)$.

23. Kamerstukken II $2013 / 14,33918,10$, p. 7.

24. HvJ EG 10 september 2009, C-199/08, ECLI:EU:C:2009:538, NJ 2009/593, m.nt. H.B. Krans (Eschig/Uniqa).

25. Zie over die algemene voorwaarden de conclusie van A-G Trstenjak voor dit arrest, sub 13. groot aantal verzekerden schade lijdt door hetzelfde feit. ${ }^{26} \mathrm{Het}$ Europese Hof wijst er in zijn arrest onder meer op dat art. 4,6 en 7 van de richtlijn en de bij die bepalingen aan de verzekerde verleende rechten ertoe strekken de verzekerden ruim te beschermen. ${ }^{27}$ Bovendien blijkt uit de formulering van art. 3 tot en met 5 van de richtlijn dat aan iedere verzekerde een algemeen en autonoom ${ }^{28}$ recht is verleend om binnen de grenzen van die artikelen zijn rechtshulpverlener vrij te kiezen. Ook heeft art. 4 een algemene strekking en een bindend karakter, aldus het Europese Hof. ${ }^{29}$ Een verzekeraar kan dus niet bedingen dat hij bij een massaschadegeval zelf de advocaat aanwijst voor alle betrokken verzekerden. Ook buiten het Alpenland heeft de uitspraak aandacht gekregen. In ons land heeft Eschig/Uniqa bijvoorbeeld geleid tot Kamervragen. ${ }^{30}$

\subsection{Beperking tot de plaats waar de procedure wordt gevoerd?}

Oostenrijk was ook de bron voor de tweede Europese beslissing over de richtlijn. ${ }^{31}$ Wederom speelde art. 4 van de richtlijn een voorname rol. Ditmaal ging het echter niet over de vraag of verzekerde Stark recht had op vrije advocaatkeuze. Verzekeraar DAS had namelijk aangegeven Starks advocatenkosten te zullen dekken. De gekozen advocaat hield echter kantoor op 600 kilometer van de plaats (Wenen) waar de procedure gevoerd zou worden. Gevolg was dat de declaraties hoger zouden uitvallen dan indien er een Weense advocaat zou zijn gekozen. DAS wilde dan ook de declarabele kosten beperken tot de kosten die normaal worden gerekend door een advocaat die is gevestigd in de plaats van de rechtbank waar de procedure wordt gevoerd.

Het Europese Hof wordt de vraag voorgelegd of de Richtlijn rechtsbijstandverzekeringen zich verzet tegen een nationale regeling krachtens welke contractueel kan worden overeengekomen dat de advocaatkeuze beperkt is tot advocaten die kantoor houden in de plaats waar de procedure zal worden gevoerd. Volgens het Hof verzet de richtlijn zich daar niet tegen, voor zover deze beperking slechts betrekking heeft op de reikwijdte van de dekking van de advocatenkosten door de verzekeraar, en de door deze verzekeraar werkelijk betaalde kosten toereikend zijn. De verwijzende rechter dient na te gaan of dat het geval is. Dat de verzekerde de additionele kosten die ontstaan door de afstand tussen het kantoor van de

26. HvJ EG 10 september 2009, C-199/08, ECLI:EU:C:2009:538 (Eschig/ Uniqa), sub 68.

27. HvJ EG 10 september 2009, C-199/08, ECLI:EU:C:2009:538 (Eschig/ Uniqa), sub 45.

28. Het Europese Hof hanteert het woord 'autonoom' om, naar wij aannemen, aan te geven dat het een onafhankelijk of zelfstandig recht betreft. In de Engelse versie van de uitspraak spreekt het Hof van 'independent way', in de Duitse vertaling van 'eigenständig'.

29. HvJ EG 10 september 2009, C-199/08, ECLI:EU:C:2009:538 (Eschig/ Uniqa), respectievelijk sub 46 en 47.

30. Aanhangsel Handelingen II 2010/11, 560, Antwoord 2, 3 en 4 (waarover Krans in zijn $N J$-noot onder Eschig/Uniqa, sub 9).

31. HvJ EU 26 mei 2011, C-293/10, ECLI:EU:C:2011:355, NJ 2011/534 (Stark/DAS). 
advocaat en de bevoegde rechterlijke instantie zelf moet dragen, beperkt dus niet de vrije advocaatkeuze. ${ }^{32}$

\subsection{Een ondergrens: redelijke keuze van de verzekerde}

Een prejudiciële vraag van de Hoge Raad leidde tot een volgende Europese beslissing over de materie. ${ }^{33}$ De heer Sneller was ontslagen en wilde tegen zijn voormalige werkgever procederen in verband met zijn ontslag. Sneller was verzekerd voor rechtsbijstand bij Reaal Schadeverzekeringen, waarbij DAS volgens de verzekeringsovereenkomst was belast met de dekking van de rechtsbijstand. DAS schakelde een eigen medewerker in, maar Sneller verlangde bijstand van een advocaat naar eigen keuze, wiens honorarium hij wilde declareren bij zijn verzekeraar. De toepasselijke algemene voorwaarden bepaalden echter dat zaken zouden worden behandeld door medewerkers van DAS en dat het recht van de verzekerde op een zelf gekozen advocaat slechts aan de orde was indien de zaak krachtens de voorwaarden of naar mening van DAS moest worden uitbesteed. Hiermee was dus in feite een naturaverzekering afgesloten: DAS zou in beginsel zelf de rechtsbijstand verlenen. Derhalve was DAS van mening dat het Sneller vrijstond een eigen advocaat te kiezen, maar dat zij daarvan de kosten niet hoefde te dragen.

De Hoge Raad vraagt het Hof van Justitie of art. 4 lid 1 van de richtlijn dit beleid toelaat, en tevens of daarbij relevant is of voor de desbetreffende procedure rechtsbijstand al dan niet verplicht is. ${ }^{34}$ Het Europese Hof oordeelt hierop dat het artikel zich ertegen verzet dat een rechtsbijstandverzekeraar die in zijn verzekeringsovereenkomsten regelt dat rechtsbijstand in gerechtelijke of administratieve procedures in beginsel wordt verleend door zijn werknemers, tevens bedingt dat de kosten van rechtsbijstand van een door de verzekerde vrij gekozen advocaat of rechtsbijstandverlener slechts vergoed kunnen worden indien de verzekeraar van mening is dat de behandeling van de zaak moet worden uitbesteed. ${ }^{35}$ Daarbij maakt het geen verschil of rechtsbijstand in de procedure verplicht is. Geheel onbeperkt is de kostenvergoeding echter niet: beperkingen zijn mogelijk zolang het recht op vrije advocaatkeuze niet van zijn inhoud wordt beroofd. ${ }^{36}$ Dat zou het geval zijn indien het voor de verzekerde in de praktijk onmogelijk wordt een redelijke keuze te maken wat zijn vertegenwoordiger betreft.

32. Overigens is het onderwerp vrije advocaatkeuze ook in Oostenrijkse literatuur niet onopgemerkt gebleven; zie bijv. M. Brunner, Die freie Anwaltswabl in der Rechtsschutzversicherung, Wenen: Verlag Österreich 2017.

33. HvJ EU 7 november 2013, C-442/12, ECLI:EU:C:2013:717 (Sneller) $D A S)$. Zie over dit arrest ook M.A. Fierstra, 'Sneller: de opportuniteit van de weg via Luxemburg', $N t E R$ 2014, afl. 4, p. 123-131. Naar aanleiding van het geschil voor de nationale rechter gaat Fierstra in op overwegingen voor de nationale rechter om op basis van art. 67 VWEU een vraag te stellen aan het Hof van Justitie.

34. HR 28 september 2012, ECLI:NL:HR:2012:BW7507, NJ 2012/567.

35. Zie voor uitgebreider commentaar op dit arrest van het Europese Hof de noot van H.B. Krans bij HR 21 februari 2014, ECLI:NL:HR:2014:396, NJ 2015/55, par. 14-22.

36. Zie r.o. 26-28 van het arrest van het Hof, o.m. onder verwijzing naar Stark/DAS
Ons inziens ziet het oordeel van het Europese Hof op de combinatie van een contractueel beding dat de rechtsbijstand wordt verleend door werknemers (naturaverzekering) en een beding dat bepaalt dat de kosten van rechtsbijstand van een door de verzekerde vrij gekozen advocaat of rechtsbijstandverlener slechts vergoed kunnen worden indien de verzekeraar van mening is dat de behandeling van de zaak moet worden uitbesteed. Dat volgt naar ons idee uit de bewoordingen die het Europese Hof hanteert. ${ }^{37}$ Het is niet ondenkbaar dat deze uitspraak daarmee de naturaverzekering haar bestaansrecht ontneemt. Dat de verzekerde een bepaalde vrijheid krijgt om een externe rechtshulpverlener in te schakelen, toont immers aan de essentie van de naturaverzekering: dat de verzekeraar zelf rechtshulp verleent. ${ }^{38}$ Overigens is de beslissing van het Europese Hof niet zonder meer hartelijk ontvangen, vanwege het gebrek aan inzicht dat het Hof geeft in zijn beslissing. Opgemerkt is dat er genoeg te zeggen is voor een beperktere uitleg van het recht op vrije advocaatkeuze, nu dat de rechtsbijstand een stuk betaalbaarder had gehouden. ${ }^{39}$

\subsection{Administratieve procedures?}

In april 2016 doet het Hof op één dag twee uitspraken over de reikwijdte van de richtlijn. ${ }^{40}$ De zaken betreffen prejudiciële vragen gesteld door de Hoge Raad respectievelijk het Gerechtshof Amsterdam. De werkgever van Massar had het UWV verzocht om toestemming tot beëindiging van de arbeidsovereenkomst met Massar wegens bedrijfseconomische redenen. Büyüktipi leed aan verschillende psychische en fysieke aandoeningen, maar door het Centrum Indicatiestelling Zorg werd afwijzend op een aanvraag van een zorgindicatie beslist. Afzonderlijk van elkaar wilden Massar en Büyüktipi bijstand in de juridische procedures die rezen, maar dat werd hun geweigerd door hun rechtsbijstandverzekeraars. De verzekeraars stelden dat met 'administratieve procedure' slechts een procedure bij de overheidsrechter werd bedoeld en dat daarmee dus delen van de bestuursrechtsgang zouden zijn uitgesloten. Daarmee kwam het aan op de vraag naar de reikwijdte van het begrip 'administratieve procedure' in art. 4 van de richtlijn. De richtlijn zelf is spaarzaam met het definiëren van gebruikte begrippen, ook wat betreft de begrippen 'gerechtelijke of administratieve procedure. ${ }^{41}$

In beide zaken overweegt het Hof van Justitie dat een beperking van het begrip tot enkel gerechtelijke procedures in bestuursaangelegenheden, dat wil zeggen procedures voor een gerecht in eigenlijke zin die ertoe strekken de rechtmatigheid van besluiten te doen toetsen en de rechtspositie van de

37. Getuige het woord 'tevens', r.o. 29.

38. Waarover meer hierna in par. 4.

39. D.B. Holthinrichs, 'Arrest van het HvJ EU van 7 november 2013 inzake Sneller tegen DAS Nederlandse Rechtsbijstand Verzekeringsmaatschappij NV', NTHR 2013, afl. 6, p. 346-352, hier p. 350 (hierna: Holthinrichs 2013a).

40. HvJ EU 7 april 2016, C-460/14, ECLI:EU:C:2016:216, NJ 2016/392 (Massar) en HvJ EU 7 april 2016, C-5/15, ECLI:EU:C:2016:218, JOR 2016/236, m.nt. J.B. Londonck Sluijck (Büyüktipi).

41. Zie in deze zin al eerder de noot van Krans bij HR 21 februari 2014 , ECLI:NL:HR:2014:396, NJ 2015/55, par. 30-32. 
belanghebbende definitief te bepalen, de betekenis van het begrip 'administratieve procedure' zou ontnemen. Bovendien moet worden gekeken naar de context en doelstelling van de bepaling, die beoogt ruime bescherming te bieden aan de verzekerde en derhalve een ruime uitleg behoeft. ${ }^{42}$ Uit beide zaken blijkt volgens het Hof voorts een behoefte aan rechtsbescherming voor de verzekerden. Wat betreft de zaak Massar betekent dat, dat het begrip 'administratieve procedure' mede omvat een procedure die ertoe leidt dat een bestuursorgaan de werkgever vergunning verleent de voor rechtsbijstand verzekerde werknemer te ontslaan. In Büyüktipi valt de fase van bezwaar bij een bestuursorgaan waarin dat orgaan een voor beroep in rechte vatbaar besluit geeft, onder het begrip. Hiermee wordt duidelijk dat ook de Nederlandse bestuursrechtsgang wordt bestreken door het recht op vrije advocaatkeuze.

Het Hof van Justitie gaat ook in op de mogelijke financiële gevolgen voor de rechtsbijstandverzekeraars. De verzekeraars hebben aangevoerd dat een ruime uitleg van het recht op vrije advocaatkeuze ertoe zou leiden dat elke rechtsbijstandverzekering de facto een kostenverzekering wordt. Het Europese Hof gaat daar niet in mee: de keuzevrijheid van de verzekeraars tussen de verschillende waarborgen uit art. 3 blijft in stand. De verzekeraars kunnen daardoor nog steeds naturaverzekeringen aanbieden, ook indien uit art. 4 een autonoom recht op vrije advocaatkeuze wordt afgeleid. Daarnaast kunnen de eventuele financiële gevolgen voor de stelsels van rechtsbijstandverzekeringen niet leiden tot restrictieve uitleg van art. 4, nu de lidstaten vrij blijven om nationale regelingen vast te stellen en er in bepaalde gevallen beperkingen kunnen worden gesteld aan de kosten die worden vergoed.

Het recht op vrije advocaatkeuze staat ons inziens echter in de weg aan een beding bij een naturaverzekering dat bepaalt dat kosten van rechtsbijstand van een door de verzekerde vrij gekozen advocaat of rechtsbijstandverlener slechts vergoed kunnen worden indien de verzekeraar van mening is dat de behandeling van de zaak moet worden uitbesteed. ${ }^{43} \mathrm{Het}$ is dan ook maar de vraag in hoeverre die keuzevrijheid voor verzekeraars daadwerkelijk ook uit te oefenen is. In principe bestaat het recht op vrije advocaatkeuze immers in elk geschil en de uitoefening daarvan is niet gebonden aan consent van de verzekeraar. Daarbij biedt de verwijzing naar mogelijke beperkingen van kosten niet veel meer dan een schrale troost voor de verzekeraars. Het is naar ons idee nog maar zeer de vraag of het Hof van Justitie beperkingen van vergoedingen voor advocaatkosten snel zal omarmen. Dergelijke beperkingen kunnen het recht op een vrije advocaatkeuze immers uithollen.

\subsection{Europese nadruk op de vrije advocaatkeuze}

Uit het bovenstaande blijkt dat het Hof van Justitie het recht op vrije advocaatkeuze een ruim toepassingsbereik toedicht. De ruime bescherming die de richtlijn beoogt te bieden, speelt daarbij voor het Hof een belangrijke rol. Het recht op vrije advocaatkeuze kan ons inziens niet worden beperkt door de combinatie van een naturaverzekering en een beding dat

42. Onder verwijzing naar Eschig/Uniqa en Sneller/DAS.

43. Zie par. 3.3. bepaalt dat kosten van rechtsbijstand van een door de verzekerde vrij gekozen advocaat of rechtsbijstandverlener slechts vergoed kunnen worden indien de verzekeraar van mening is dat de behandeling van de zaak moet worden uitbesteed. Voorts wordt het begrip 'administratieve procedure' ruim uitgelegd, waardoor de Nederlandse bestuursrechtsgang eronder kan worden geschaard. De vergoedingsplicht van de verzekeraar kan onder omstandigheden echter worden beperkt. Met de uitleg die het Hof van Justitie in genoemde rechtspraak heeft gegeven aan het recht op vrije advocaatkeuze, is het gewicht van dat recht toegenomen.

\section{Nederland: aanpassing verzekeringen?}

De Europese dimensie van de materie heeft ook in ons land, als gezegd, voor reuring gezorgd. Zo zijn er sinds het Europese arrest Eschig/Uniqa in ons land nogal wat zaken aanhangig gemaakt over dit recht op vrije advocaatkeuze. ${ }^{44}$ Ook de Europese zaken Sneller/Das, Massar en Büyüktipi zijn afkomstig uit ons land. Wij gaan in op enkele aspecten van de betekenis van de Europese rechtspraak voor het Nederlandse recht. ${ }^{45}$

De naturaverzekering speelt (of speelde), als gezegd, in de Nederlandse praktijk van rechtsbijstandverzekeringen een belangrijke rol. ${ }^{46}$ Uit parlementaire stukken blijkt dat aanvankelijk de gedachte was dat het recht op vrije advocaatkeuze bij een naturaverzekering pas aan de orde komt waar de rechtsbijstandverzekeraar besluit dat een advocaat of andere bevoegde deskundige ingeschakeld dient te worden. ${ }^{47}$ Tussen deze zienswijze en het Europese recht is een zekere spanning ontstaan door Sneller/DAS. Daarin is immers geoordeeld dat een combinatie van een contractueel beding dat de rechtsbijstand wordt verleend door werknemers en een beding dat bepaalt dat de kosten van rechtsbijstand van een door de verzekerde vrij gekozen advocaat of rechtsbijstandverlener slechts vergoed kunnen worden indien de verzekeraar van mening is dat de behandeling van de zaak moet worden uitbesteed, in strijd is met de richtlijn. In het licht van Sneller/DAS is naar ons idee de genoemde opvatting van de wetgever dan ook niet meer

44. Bijv. Rb. Amsterdam 8 maart 2011, ECLI:NL:RBAMS:2011:7547, Rb. Den Haag 25 april 2012, ECLI:NL:RBSGR:2012:BX2028, Hof Arnhem-Leeuwarden 12 maart 2013, ECLI:NL:GHARL:2013:BZ5184 (en overige rechtspraak genoemd in de noot van Krans ad NJ 2015/55, sub 8).

45. De wetgever heeft er destijds overigens voor gekozen de keuzevrijheid die art. 3 Richtlijn rechtsbijstandverzekeringen biedt te beperken voor multibrancheverzekeraars, omdat het risico op belangenverstrengeling daar groter is. In de oorspronkelijke MvT merkt de wetgever op dat de gevolgen daarvan voor de Nederlandse praktijk gering zullen zijn, nu in de jaren zestig multibrancheverzekeraars al zijn overgegaan tot de oprichting van juridisch zelfstandige schaderegelingskantoren om een zo onafhankelijk mogelijke schadeafhandeling te hebben (Kamerstukken II 1988/89, 21076,3 , p. 3). Op dit vlak zal de invloed van de Europese rechtspraak dus niet groot zijn geweest.

46. Vgl. Holthinrichs 2013, p. 157.

47. Kamerstukken II 1988/89, 21076, 3, p. 4 en 6, p. 5. Zie ook Kamerstukken II 2005/06, 29708, 19, p. 541. 
houdbaar. ${ }^{48} \mathrm{Als}$ reactie op de uitspraak van het Hof van Justitie zijn er daarom aanpassingen in art. 4:67 Wft doorgevoerd. ${ }^{49}$ De parlementaire toelichting bij die wijzigingen zoekt aansluiting bij het Europese arrest Sneller/DAS en het daaropvolgende arrest van de Hoge Raad in die zaak. ${ }^{50}$

Voor de zuivere naturaverzekering, waarin wordt bepaald dat in beginsel de verzekeraar de rechtsbijstand zelf verleent en waarbij een uitzondering mogelijk is met instemming van de verzekeraar, is sinds Sneller/DAS dus in wezen geen ruimte meer. Dat bevestigt de Hoge Raad in zijn eindarrest in die zaak: '(...) het recht op vrije keuze van een rechtshulpverlener [is] niet afhankelijk (...) van een besluit van de rechtsbijstandverzekeraar dat de zaak door een externe rechtshulpverlener zal worden behandeld. 51

In reactie op Kamervragen van de SP heeft de staatssecretaris opgemerkt dat er contact is geweest tussen de ministeries van Veiligheid en Justitie en Financiën en het Verbond van Verzekeraars $(\mathrm{VvV}) .{ }^{52}$ Het $\mathrm{VvV}$ heeft aangegeven dat de verzekeraars, waar nodig, hun polisvoorwaarden hebben aangepast. Een marginale inventarisatie laat zien dat dit inderdaad het geval blijkt te zijn. ${ }^{53}$ Hoewel verzekeraars in de polisvoorwaarden nog lijken aan te dringen op behandeling door een eigen rechtshulpverlener, betekent dit dat de zuivere naturaverzekering verleden tijd is. Wel leren de onderzochte polisvoorwaarden dat verzekerden pas dan een eigen advocaat kunnen kiezen, indien het nodig is een administratieve of gerechtelijke procedure te voeren of de tegenpartij juridische hulp krijgt van dezelfde verzekeraar. De vraag rijst daarbij hoe wordt beslist of een procedure nodig is. Overigens is goed voorstelbaar dat verzekerden in bepaalde gevallen gebaat kunnen zijn bij een externe advocaat indien er (nog) geen procedure aanhangig is gemaakt. $^{54}$

48. Zo ook A-G Spier reeds voordat het Hof uitspraak deed in Sneller/DAS zie zijn conclusie (ECLI:NL:PHR:2012:BW7507, onder 4.24.1) voor het arrest waarin de Hoge Raad prejudiciële vragen stelt: HR 28 september 2012, ECLI:NL:HR:2012:BW7507, NJ 2012/567. Hetzelfde geldt overigens voor opvattingen in de literatuur. Zo betoogt Boshuizen in 2001 nog dat de verzekeraar altijd voor interne behandeling kan opteren, waardoor de vrije advocaatkeuze pas aan de orde zou komen indien de verzekeraar besluit de zaak extern te laten behandelen. Daardoor zou een gerechtelijke of administratieve procedure ook door medewerkers van de verzekeraar kunnen worden gevoerd, waardoor de verzekerde in zo'n geval niet vrij zijn advocaat kan kiezen. Zie G.R. Boshuizen, Verzekeringen, overheidstoezicht en privaatrecht, Deventer: W.E.J. Tjeenk Willink 2001, p. 374.

49. Kamerstukken II 2013/14, 33918, 10.

50. Kamerstukken II 2013/14,33918, 10, p. 7

51. HR 21 februari 2014, ECLI:NL:HR:2014:396, NJ 2015/55, m.nt. H.B. Krans, r.o. 2.3.

52. Aanhangsel Kamerstukken II 2014/15, 164.

53. Daarbij zijn de polisvoorwaarden van DAS Rechtsbijstand (Algemene polisvoorwaarden 01-2016, p. 4 r.k., 7 r.k.), ARAG (Voorwaarden ProRechtPolis Particulier juli 2015, p. 4 r.k.), Centraal Beheer (Rechtsbijstandverzekering voorwaarden januari 2017, p. 9), Interpolis (Verzekeringsvoorwaarden Rechtsbijstand (LEX-RV-57-161), p. 10) en FBTO (Voorwaarden Rechtsbijstandverzekering RH2017, p. 22) op 11 februari 2018 geraadpleegd, zoals te vinden op de respectievelijke websites www. das.nl, www.arag.nl, www.centraalbeheer.nl, www.interpolis.nl en www. fbto.nl.

54. Bijv. omdat de advocaat meer relevante expertise heeft.
Volgens de Kwaliteitscode Rechtsbijstand 2014 moet het recht op vrije advocaatkeuze voor de klant 'eenvoudig raadpleegbaar' zijn op de website en in de polisvoorwaarden. ${ }^{55}$ Daarnaast moet de verzekeraar de verzekerde informeren over de vrije advocaatkeuze wanneer hij vaststelt dat een gerechtelijke of administratieve procedure gevoerd gaat worden. De Kwaliteitscode 2010 bevatte die verplichting nog niet. ${ }^{56}$ Het valt vanzelfsprekend voor verzekerden te hopen dat rechtsbijstandverzekeraars aan die verplichtingen uit de Kwaliteitscode voldoen. De genoemde inventarisatie van polisvoorwaarden leert dat het redelijk eenvoudig is het recht op vrije advocaatkeuze in heldere taal te vinden in die voorwaarden. Bijvoorbeeld:

' $U$ mag zelf een rechtshulpverlener kiezen, als het nodig is om namens $u$ een gerechtelijke of administratieve procedure te voeren. In veel gevallen kan de juridisch specialist van DAS die procedure voor u voeren. Maar als u dat wilt, mag u ook een rechtshulpverlener kiezen die niet bij DAS in dienst is. Bijvoorbeeld een advocaat. Dit noemen wij een externe rechtshulpverlener. ${ }^{57}$

Verzekeraars trachten wel grip op de keuze voor een externe rechtshulpverlener te houden, bijvoorbeeld door te vereisen dat ze die zelf inschakelen, of dat ze op de hoogte worden gehouden van het verloop van de zaak.

Een ander gevolg van het gewicht dat het Hof aan de vrije advocaatkeuze toekent, is dat belangenverenigingen die niet primair als rechtsbijstandverzekeraar optreden wel degelijk als zodanig gekwalificeerd kunnen worden in het kader van de Wft indien ze vergelijkbare diensten aanbieden. ${ }^{58}$ In dat geval moeten ze het recht op vrije advocaatkeuze ook honoreren. Een volgende stap zou dan kunnen zijn dat het recht op vrije advocaatkeuze ook van toepassing is op verzekeringen van een bepaald risico met een additionele rechtsbijstandsdekking, zoals een autoverzekering. ${ }^{59}$ Rechtsbijstand is dan alleen verze-

55. Art. 4.5 Kwaliteitscode Rechtsbijstandsverzekeraars (versie 2014), geraadpleegd (in december 2017) op de site van het Verbond van Verzekeraars.

56. Art. 4.5 Kwaliteitscode Rechtsbijstandsverzekeraars (versie 2010), o.m. te raadplegen via www.centraalbeheer.nl/cb\%20downloads/kwaliteitscode rechtsbijstand.pdf (geraadpleegd op 24 februari 2018). Van Boom 2011 merkte destijds al op dat het belangrijk was dat verzekeraars niet slechts het recht op vrije advocaatkeuze opnemen in de polisvoorwaarden, maar die voorwaarden ook 'actief uitdragen in hun communicatie met verzekerden'. De Kwaliteitscode lijkt hem daarin te zijn gevolgd. Vgl. ook de verplichting in art. 7 Richtlijn rechtsbijstandverzekeringen (art. 204 Richtlijn Solvabiliteit II).

57. DAS Rechtsbijstand, Algemene polisvoorwaarden 01-2016, p. 3.

58. Zie Hof Arnhem-Leeuwarden 16 mei 2017, ECLI:NL:GHARL: 2017:4365, r.o. 3.7. Begin 2013 oordeelde datzelfde hof nog in een soortgelijk geval dat de vereniging niet als rechtsbijstandverzekeraar gekwalificeerd kon worden: Hof Arnhem-Leeuwarden 12 maart 2013, ECLI:NL:GHARL:2013:BZ5184.

59. Zie bijv. de polisvoorwaarden van de autoverzekeringen van Centraal Beheer (Autoverzekering voorwaarden januari 2017, p. 5), FBTO (Voorwaarden Autoverzekering, p. 24) en Interpolis (Verzekeringsvoorwaarden (PAV-RV-56-161) Auto WA, p. 5), te raadplegen via www. centraalbeheer.nl, www.fbto.nl en www.interpolis.nl (geraadpleegd op 4 februari 2018). 
kerd in verband met geschillen die verwezenlijking van het verzekerde risico betreffen. Dit is echter een brug te ver. Het gaat hier om de vergoeding van kosten van een rechtszaak tegen de verzekerde in het kader van de wettelijke aansprakelijkheidsverzekering. ${ }^{60}$ Zowel de richtlijn als de Wft sluit toepassing uit van werkzaamheden 'ter verdediging of vertegenwoordiging van een verzekerde die een verzekeraar krachtens een overeenkomst van aansprakelijkheidsverzekering mede in zijn eigen belang verricht ${ }^{61}$ Die keuze is logisch omdat in zo'n geval de belangen van verzekeraar en verzekerde gelijkgesteld zijn. Eventuele belangenconflicten die ontstaan omdat de verzekeraar de vorderende partij voor rechtsbijstand heeft verzekerd, worden ondervangen door de vrije advocaatkeuze in die verzekeringsrelatie.

\section{Winst voor verzekerden?}

Het ligt voor de hand te veronderstellen dat verzekerden als gevolg van de Europese rechtspraak zullen trachten vaker een advocaat in te schakelen op kosten van de rechtsbijstandverzekeraar. Of dat vaak zal gebeuren, weten we echter niet. London Sluijck heeft opgemerkt dat de ervaring leert dat ondanks de mogelijkheid van vrije advocaatkeuze het overgrote deel van de verzekerden instemt met voorstellen voor rechtsbijstandverlening door eigen werknemers of advocaten die met de verzekeraar prijsafspraken hebben. ${ }^{62}$ Bovendien wordt een zekere mate van proactiviteit verwacht van verzekerden, ${ }^{63}$ ook omdat sommige polisvoorwaarden nog behandeling door een interne rechtshulpverlener aansporen. Dat brengt het risico met zich mee dat een eventuele premiestijging van rechtsbijstandverzekeringen als het gevolg van toenemende inschakeling van externe rechtshulpverleners, disproportioneel voor rekening van niet-proactieve verzekerden komt.

Indien verzekerden inderdaad vaker een beroep doen op het recht op vrije advocaatkeuze kan dat tot gevolg hebben dat de kosten van rechtsbijstandverzekeringen stijgen. Ook de staatssecretaris heeft dat al aangegeven. ${ }^{64}$ Het Hof van Justitie laat in Sneller/DAS ruimte voor beperkingen van kostenvergoedingen door verzekeraars. Wij kunnen ons voorstellen dat dit voor verzekeraars niet eenvoudig manoeuvreren is. ${ }^{65} \mathrm{Uit}$ genoemde marginale inventarisatie blijkt dat verzekeraars bijvoorbeeld verzekerden eigen risico laten betalen bij het inscha- kelen van een externe advocaat ${ }^{66}$ of kostenvergoeding van een externe advocaat beperken waar in een procedure geen verplichte procesvertegenwoordiging is. ${ }^{67}$ Onduidelijk is echter of zulke beperkingen daadwerkelijk in overeenstemming zijn met de Europese rechtspraak. Daarnaast blijven verzekeraars bepalen of een administratieve of gerechtelijke procedure noodzakelijk is, waarin het recht op vrije advocaatkeuze pas aan bod komt. Wel kunnen interne geschillenregelingen van verzekeraars bij een conflict hierover mogelijk soelaas bieden voor de verzekerde. ${ }^{68}$ De vraag rijst in hoeverre de verzekerde nu uiteindelijk gebaat is bij de rechtspraak van het Hof van Justitie. Inderdaad mag hij in meer gevallen een eigen advocaat kiezen. De keerzijde zou kunnen zijn dat de premies stijgen en/of de vergoeding via een andere weg is beperkt, en/of dat verzekeraars terughoudender zullen zijn met het instemmen met een procedure. ${ }^{69}$

\section{Ter afsluiting}

De Richtlijn rechtsbijstandverzekeringen en de Europese rechtspraak hebben het een en ander losgemaakt voor de Nederlandse praktijk. Voor mondige verzekerden biedt die rechtspraak de kans om eerder een vrije advocaatkeuze te maken, op kosten van hun rechtsbijstandverzekeraar. Dit heeft echter mogelijk ook een nadelige keerzijde voor de verzekerden, bijvoorbeeld in verband met eventuele premiestijging of een mindere bereidheid van verzekeraars om te procederen. De rechtspraak van het Hof van Justitie heeft daarnaast ertoe geleid dat (in elk geval sommige) rechtsbijstandverzekeringen zijn aangepast. Een marginale zoektocht langs enkele voorwaarden die verzekeraars hanteren, doet ons vermoeden dat verzekeraars op zoek zijn naar beperkingen aan de vergoedingsplicht voor deze kosten. Of nadere wijzigingen in het verschiet liggen, weten wij niet. Beperkingen aan de vergoedbaarheid zullen uiteindelijk een eventuele toets van het Europese Hof van Justitie wel moeten kunnen doorstaan. Dat Hof laat immers beperkingen aan de vergoedbaarheid van de kosten van een zelf gekozen advocaat toe, maar niet onbeperkt.
60. Polisvoorwaarden van de autoverzekeringen van Centraal Beheer (Autoverzekering voorwaarden januari 2017, p. 5), FBTO (Voorwaarden Autoverzekering, p. 24) en Interpolis (Verzekeringsvoorwaarden (PAVRV-56-161) Auto WA, p. 5), te raadplegen via www.centraalbeheer.nl, www.fbto.nl en www.interpolis.nl (geraadpleegd op 4 februari 2018).

61. Citaat uit Wft, Bijlage branches, par. 17; art. 198 lid 2 sub b Richtlijn Solvabiliteit II.

62. J.B. London Sluijck, noot bijJOR 2016/237, sub 6 .

63. Vgl. Commissie van Beroep (KiFiD) 8 mei 2014, nr. 2014/017, par. 4.3 .

64. Aanhangsel Kamerstukken II 2014/15, 164, p. 1 en 2.

65. Zo ook Holthinrichs 2013a, p. 350-351, die een aantal mogelijkheden voor verzekeraars schetst, waaronder sturen op de te betalen uurtarieven van advocaten, kostenmaxima en het uitsluiten van zaken waarin relatief vaak moet worden geprocedeerd. Daarbij opereren verzekeraars in een precair spanningsveld: het is bijv. niet toegestaan de keuze te beperken tot een bepaald aantal door de verzekeraar aan te wijzen advocaten, geselecteerd naar honoraria. Zie Kamerstukken II 1988/89, 21076, 6, p. 7.
66. Zie Algemene polisvoorwaarden (01-2016) van Das, p. 5 l.k., geraadpleegd op 11 februari 2018 via www.das.nl.

67. Zie Voorwaarden Rechtsbijstandverzekering RH2017 van FBTO, p. 18, geraadpleegd op 11 februari 2018 via www.fbto.nl.

68. Vgl. art. 6 Richtlijn rechtsbijstandverzekeringen (art. 203 Richtlijn Solvabiliteit II).

69. Daarbij moet worden vermeld dat art. 7:940 lid 4 BW eenzijdige aanpassing van de verzekeringsvoorwaarden door de verzekeraar, ook ten nadele van de verzekerde, toestaat. Alle geraadpleegde polisvoorwaarden kennen dat recht aan de verzekeraar toe. Dat biedt ruimte voor verzekeraars om eenzijdig premiestijgingen door te voeren of verdere kostenbeperkingen in de voorwaarden op te nemen, waardoor ook bestaande verzekerden getroffen kunnen worden. Art. 7:940 lid 4 BW biedt aan de verzekerde bescherming door te bepalen dat deze de verzekering als gevolg van de anpassing mag opzeggen. De vraag is echter in hoeverre dat in de praktijk toereikend is: de drempel om over te stappen zal hoog zijn. 